14.2

\title{
Самоорганизация биоактивного наноструктурированного оксидного слоя на поверхности спеченного порошка губчатого титана при электрохимическом анодировании
}

\author{
(C) А.Н. Кокатев, ${ }^{1}$ К.В. Степанова, ${ }^{1}$ Н.М. Яковлева, ${ }^{1}$ В.Е. Толстик, ${ }^{2}$ А.И. Шелухина, ${ }^{2}$ А.М. Шульга ${ }^{1}$ \\ ${ }^{1}$ Петрозаводский государственный университет, \\ 185910 Петрозаводск, Россия \\ ${ }^{2}$ Государственное научное учреждение „Институт порошковой металлургии“, \\ 220005 Минск, Беларусь \\ e-mail: nmyakov@petrsu.ru
}

(Поступило в Редакцию 16 января 2018 г.)

Показана возможность получения самоорганизованных нанопористых/нанотрубчатых оксидных пленок при электрохимическом анодировании пористых порошковых материалов из губчатого титана. Методами сканирующей электронной и зондовой микроскопий установлено, что при анодировании в электролите $10 \% \mathrm{H}_{2} \mathrm{SO}_{4}+0.15 \% \mathrm{HF}$ на поверхности микрочастиц спеченного порошка губчатого титана формируется рентгеноаморфная пленка $\mathrm{TiO}_{2}$ толщиной порядка $250-350 \mathrm{~nm}$, характеризующаяся присутствием регулярно расположенных пор/трубок с эффективным диаметром от 30 до $70 \mathrm{~nm}$. Полученные результаты подтверждают перспективность применения такого способа модификации поверхности спеченных порошков губчатого титана при изготовлении биоактивных имплантатов.

DOI: $10.21883 /$ JTF.2018.09.46424.25-18

\section{Введение}

В настоящее время наибольшее распространение для изготовления имплантатов получили Ті и ряд его сплавов, прежде всего из-за высокой биосовместимости, малого коэффициента линейного расширения, а также нетоксичности [1]. Компактные титановые имплантаты успешно применяются в ортопедии и травматологии, однако они плохо подходят для замещения утраченной костной ткани в виду нестабильной фиксации и слабой остеоинтеграции. Решение этих проблем достигается путем изготовления имплантатов из пористого титана, которые по своей структуре и физико-механическим свойствам близки к костной ткани [2,3]. Пористые порошковые материалы, получаемые методами обработки давлением и спеканием порошков губчатого Тi, обладают комплексом уникальных физико-химических и биохимических свойств, среди которых бактерицидный эффект, ускоренная остеоинтеграция с костной тканью и другие $[4,5]$. Такие особенности спеченных порошков губчатого титана определяются, прежде всего, структурой поверхности частиц порошка $[5,6]$.

Улучшение приживаемости титановых имплантатов, как правило, достигается модификацией их поверхности. Перспективным для обработки поверхности имплантата является электрохимическое анодирование, формирующее на поверхности титана биоактивный нанотрубчатый слой диоксида титана [7-10].

Особенностям роста анодных оксидных пленок (АОП) во фторсодержащих электролитах на поверхности компактного титана посвящен целый ряд обзоров [7,11-14]. Известно, что при анодировании титана во фторсодержащих электролитах формируются самоорганизованные нанотрубчатые оксидные пленки с диаметром трубок и толщиной, задаваемыми условиями процесса. Причем формирование АОП может быть осуществлено на образцах произвольной формы. К настоящему моменту был выполнен ряд исследований, выявивших положительное воздействие нанотрубчатого $\mathrm{TiO}_{2}$ как на рост клеток, так и на скорость образования гидроксиапатита $[7,9,10]$. Формирование в результате анодирования нанотрубчатого слоя $\mathrm{TiO}_{2}$ приводит к увеличению удельной поверхности имплантата, улучшает коррозионную стойкость, способствует гидрофильности и, таким образом, значительно улучшает биосовместимость по сравнению с немодифицированными поверхностями [15].

Известен ряд работ, посвященных формированию биоактивных оксидных покрытий на поверхности так называемых пористых титановых матриц (porous titanium scaffold), полученных различными методами [2,3]. С этой целью применялось как плазменно-электролитическое оксидирование (ПЭО) [16,17], так и электрохимическое анодирование [10]. Использование ПЭО позволяет получить неоднородный микропористый слой $\mathrm{TiO}_{2}$ с хорошей адгезией к титановой подложке, усиливающий остеоинтеграцию клеток [16]. В [10] показано, что анодирование пористого титана в водном растворе $2 \mathrm{M} \mathrm{H}_{3} \mathrm{PO}_{4}+0.15 \mathrm{MHF}$ создает слой нанотрубок $\mathrm{TiO}_{2}$ диаметром порядка $100 \mathrm{~nm}$, улучшающий биосовместимость металла.

Известны также работы, посвященные формированию биоактивных алмазоподобных покрытий пористых порошковых имплантатов из губчатого титана для замещения костной ткани [18]. Показано, что после нанесения такой пленки имплантат лучше и быстрее интегрирует с костной тканью. По мнению авторов, еще одним 
преимуществом такой пленки является ее долговечность в отличие от покрытия из гидроксиапатита, которое со временем растворяется в организме. Учитывая сложность предлагаемой в [18] технологии модификации поверхности, разработка более простых методов нанесения биоактивных покрытий на пористые порошковые материалы (ППМ) из губчатого титана, например электрохимического анодирования, является актуальной проблемой. Анализ литературы показал, что сведения о получении самоорганизованных нанотрубчатых или нанопористых оксидных слоев на поверхности образцов из спеченного порошка губчатого Ті при анодировании отсутствуют.

Настоящая работа посвящена получению и исследованию наноструктурированных анодных оксидных пленок на спеченных порошках губчатого титана.

\section{Объекты и методы исследования}

Объектами исследования являлись ППМ из губчатого порошка технически чистого титана марки ТПП фракции 0.63-1.00 mm. Удельная поверхность образцов составляла $1350 \mathrm{~cm}^{2} / \mathrm{g}$. Образцы изготовлены одноосным прессованием порошка губчатого титана стальным пуансоном в металлической пресс-форме при давлениях 100-120 МРа в форме дисков диаметром 20-30 $\mathrm{mm}$ и толщиной $3 \mathrm{~mm}$. Спекание дисков проводилось в вакууме при температуре $1090^{\circ} \mathrm{C}$ в течение $70 \mathrm{~min}[5,19]$.

Предварительно образцы очищались в ацетоне и этиловом спирте в ультразвуковой ванне, промывались в дистиллированной воде и сушились на воздухе при комнатной температуре. Анодирование проводилось в трехэлектродной электрохимической ячейке с танталовым катодом и платиновым противоэлектродом в водном фторсодержащем электролите $10 \% \mathrm{H}_{2} \mathrm{SO}_{4}+0.15 \% \mathrm{HF}$ как в вольтстатическом (BCP) - при постоянном напряжении, так и гальваностатическом режимах (ГСР) при постоянной плотности тока. Кинетические зависимости роста оксида $j_{a}(t)$ для вольтстатического и $U_{a}(t)$ для гальваностатического режимов регистрировались электронным самописцем ЭРБИЙ-7115, сопряженным с компьютером. Подробно методика анодирования описана в работах [20,21].

Морфология поверхности образцов изучалась методами атомно-силовой микроскопии (ACM) и сканирующей электронной микроскопии (СЭМ) с помощью сканирующего зондового микроскопа „Солвер некст“ (ЗАО „НТ-МДТ“, Россия) и высокоразрешающего сканирующего электронного микроскопа „Мira“ фирмы „Теscan“ соответственно. Для АСМ исследований образцов ППМ из губчатого титана использовалась специально разработанная для порошковых материалов методика [20]. Размер области сканирования изменялся в диапазоне от 4 до $25 \mu \mathrm{m}^{2}$ с учетом неоднородного рельефа поверхности образцов. Атомная структура образцов до и после анодирования анализировалась методом рентгеноструктурного анализа на автоматическом дифрактометре ARL
X'TRA с использованием $\mathrm{Cu} K_{\alpha}$-излучения в диапазоне углов $2 \theta=(15-90)^{\circ}$ с шагом $0.05^{\circ}$.

Смачиваемость образцов изучалась методом лежащей капли, основанном на измерении краевого угла смачивания поверхности образцов. Для оценки коррозионной стойкости образцов был использован метод контроля потенциала разомкнутой цепи (ПРЦ) в физиологическом растворе Рингер-Локка, моделирующем плазму крови. Время выдержки образцов в растворе составляло от одного до $6 \mathrm{~h}$.

\section{Результаты и их обсуждение}

Анодирование ППМ из губчатого порошка титана во фторсодержащем водном электролите осуществлялось впервые, поэтому экспериментальный поиск оптимальных условий анодирования, приводящих к формированию на поверхности образцов наноструктурированной оксидной пленки, проводился путем варьирования условий процесса (напряжения и плотности тока) с последующим анализом зависимостей $U_{a}(t)$ и $j_{a}(t)$. Вначале условия анодирования выбирались на основе имеющихся литературных данных для анодирования компактного титана $[11,12]$. Согласно $[11,12]$, для получения нанотрубчатых анодных оксидных пленок (АОП) в водном растворе $10 \% \mathrm{H}_{2} \mathrm{SO}_{4}$ с добавкой $0.15 \% \mathrm{HF}$ оптимально использование вольтстатического режима при напряжении $U_{a}=20 \mathrm{~V}$, комнатной температуре электролита $T=(20-25)^{\circ} \mathrm{C}$ и продолжительности процесса от $30 \mathrm{~min}$ до $2 \mathrm{~h}$. Следует отметить, что обычно начальный этап вольтстатического анодирования компактного титана в водных фторсодержащих электролитах осуществляется путем линейного увеличения напряжения до заданного значения со скоростями не более $1 \mathrm{~V} / \mathrm{s}$ [22].

Однако анодирование исследуемых образцов в ВСР при $U_{a}=20 \mathrm{~V}$ привело к появлению на регистрируемых зависимостях $j_{a}(t)$ скачков тока, которые по всей видимости были обусловлены пробоем барьерного слоя формируемой на поверхности микрочастиц губчатого титана АОП. По этой причине в дальнейшем анодирование проводилось при значениях напряжения, равных 10 и $15 \mathrm{~V}$, с реализацией начальной стадии вольтстатического режима плавным увеличением напряжения до заданного значения со скоростью $100 \mathrm{mV} / \mathrm{s}$. Оказалось, что анодирование при $U_{a}=15 \mathrm{~V}$ описывается зависимостью $j_{a}(t)$, характерной для роста самоорганизованных нанопористых или нанотрубчатых АОП на компактном титане и образцах из спеченных порошков алюминида титана [22,23]. При этом на кривой $j_{a}(t)$ последовательно выделяются участки, характеризующие различные стадии формирования самоорганизованных аноднооксидных пленок (рис. 1, кривая 1): участок спада тока, соответствующий образованию барьерного слоя АОП; участок замедления спада тока, свидетельствующий о начале зарождения пор из-за локального растворения барьерного слоя; участок постоянного тока, характерный для стадии стационарного роста пор/трубок. Ана- 


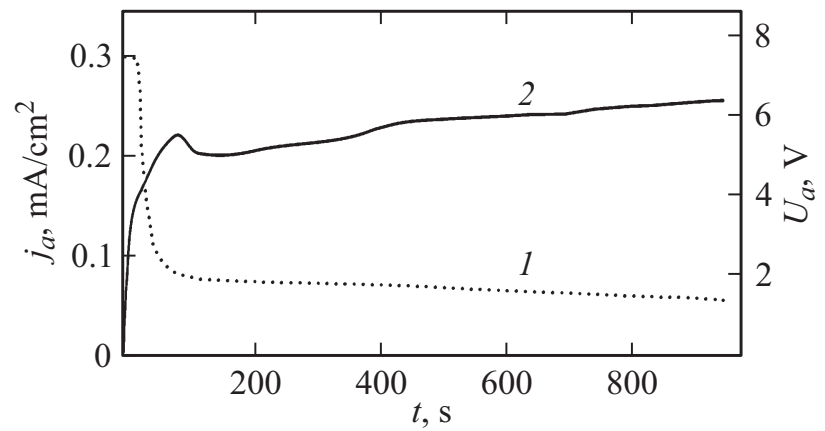

Рис. 1. Кривые $j_{a}(t) \quad(1)$ и $U_{a}(t)$ (2), полученные при анодировании образцов губчатого Ті в электролите $10 \% \mathrm{H}_{2} \mathrm{SO}_{4}+0.15 \% \mathrm{HF}\left(t_{a}=60 \mathrm{~min}, T=293 \mathrm{~K}\right)$ с использованием вольтстатического режима (ВСР) при $U_{a}=15 \mathrm{~V}(1)$ и гальваностатического режима (ГСР) при $j_{a}=0.15 \mathrm{~mA} / \mathrm{cm}^{2}(2)$. Показаны начальные участки.

логичный ход зависимости $j_{a}(t)$ наблюдался и при анодировании образцов при $U_{a}=10 \mathrm{~V}$.

Дальнейшие исследования процесса формирования АОП на образцах губчатого титана проводили в ГСР при различных значениях плотности тока в диапазоне $j_{a}=(0.1-0.3) \mathrm{mA} / \mathrm{cm}^{2}$ вблизи значения стационарной плотности тока (рис. 1, кривая 1), регистрируемой в ВСР. Наиболее характерный для формирования самоорганизованного наноструктурированного анодного оксида вид имела кривая $U_{a}(t)$, полученная при значении $j_{a}=0.15 \mathrm{~mA} / \mathrm{cm}^{2}$ (рис. 1, кривая 2). Следует отметить, что оптимальное время анодирования при $j_{a}=0.15 \mathrm{~mA} / \mathrm{cm}^{2}$ составляет $60 \mathrm{~min}$, поскольку дальнейшее продолжение процесса приводит к резкому возрастанию температуры раствора.

Таким образом, установлено, что процесс анодирования (в течение $60 \mathrm{~min}$ и комнатной температуре электролита) образцов губчатого титана во фторсодержащем водном электролите $10 \% \mathrm{H}_{2} \mathrm{SO}_{4}+0.15 \% \mathrm{HF}$ как в ВСР при значении $U_{a}=10$ и $15 \mathrm{~V}$, так и в ГСР с плотностью тока $j_{a}=0.15 \mathrm{~mA} / \mathrm{cm}^{2}$ характеризуется зависимостями $j_{a}(t)$ и $U_{a}(t)$, типичными для формирования АОП пористого/трубчатого типа. Необходимо отметить, что реализация вольтстатического режима с плавным подъемом напряжения до заданного значения на начальном этапе анодирования характеризуется хорошей воспроизводимостью вида кинетических зависимостей роста для различных образцов.

На следующем этапе было проведено микроскопическое исследование морфологии поверхности образцов ППМ губчатого титана до и после анодирования. Исследование поверхности образцов ППМ из губчатого порошка Ті методом СЭМ (рис. 2, $a$ ) показало, что микрочастицы имеют достаточно развитую морфоструктуру, характерную для титановой губки $[5,6,24]$. В работе [5] показано, что обычно частицы спеченного порошка покрыты достаточно однородной оксидной пленкой толщиной $\delta \approx 80-100 \mathrm{~nm}$. Как следует из АСМ изображений (рис. 2, $b, c$ ), на поверхности образцов наблюдаются участки с различным характером рельефа. Кроме того, отмечается присутствие выступающих округлых частиц с линейными размерами в диапазоне от 20 до $200 \mathrm{~nm}$.

Из СЭМ изображений образцов, анодированных в $10 \% \mathrm{H}_{2} \mathrm{SO}_{4}+0.15 \%$ HF при $U_{a}=15 \mathrm{~V}$ в течение $1 \mathrm{~h}$ (рис. 3), видно, что на поверхности наблюдается регулярно пористый рельеф, свидетельствующий о формировании самоорганизованной АОП с открытыми порами со средним эффективным диаметром $\left\langle d_{p}\right\rangle=(50 \pm 10) \mathrm{nm}$ (рис. 3,e).

Необходимо отметить, что для описания строения самоорганизованных АОП, в которых присутствуют регулярно расположенные поры/трубки наноразмерного диаметра, целесообразно использовать понятие мезоскопической структуры (или мезоструктуры), характеризующей взаимное расположение ячеек/пор/трубок на поверхности оксида [24]. Тогда в соответствии со степенью упорядоченности пористого/трубчатого массива оксиды можно разделить на оксиды с „аморфным“, „поликристаллическим“ и „монокристаллическим“ типом мезоструктуры [25]. В соответствии с вышесказанным пористый массив АОП, сформированный анодированием ППМ из губчатого титана, характеризуется неупорядоченным расположением пор, т.е. аморфной мезоскопической структурой.

На отдельных участках поверх пористого массива (рис. 3, a,c) присутствуют фрагменты дополнительного „дефектного“ слоя толщиной от 50 до $100 \mathrm{~nm}$. По всей видимости, они представляют собой остатки первичной оксидной пленки, покрывающей, как правило, всю поверхность микрочастиц губчатого титана [5]. Для полного удаления фрагментов дефектного слоя, характеризующихся слабой адгезией к основному пористому массиву [20], рекомендуется, согласно [7], провести обработку анодированного образца в ультразвуковой ванне.

Как видно из СЭМ изображений, приведенных на рис. $3, b, d, e$, после анодирования в оптимальных условиях гальваностатического режима на поверхности частиц губчатого титана также формируется самоорганизованная анодно-оксидная пленка пористого типа. Присутствие фрагментов дополнительного слоя в этом случае наблюдается лишь на отдельных участках поверхности анодированных образцов. Необходимо отметить, что АОП, полученные в условиях ГСР анодирования, характеризуются несколько большей локальной неоднородностью размеров пор (рис. $3, f$ ), чем пленки, сформированные вольтстатическим анодированием (рис. 3,e). Так, обнаруживаются участки с линейными размерами от 0.5 до $1 \mu \mathrm{m}$, характеризуемые различающимися диаметрами пор в диапазоне от 40 до $110 \mathrm{~nm}$. Таким образом, изучение поверхности анодированных образцов ППМ из губчатого титана методом СЭМ свидетельствует о формировании АОП с регулярно пористой, а не трубчатой мезоструктурой, которая характерна для анодирования компактного титана $[7,11,12]$.

Параллельно для изучения строения поверхности анодированных образцов был применен метод АСМ. Как 


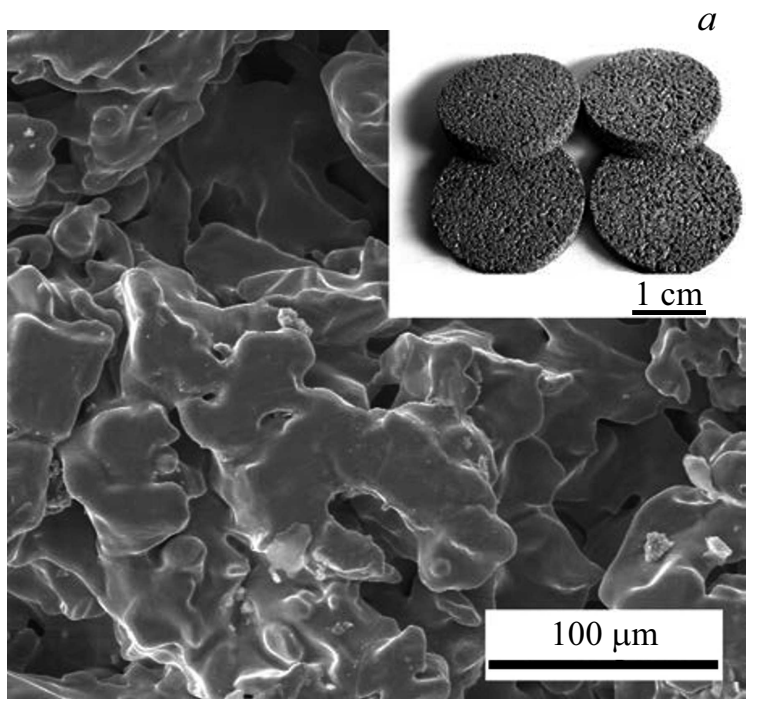

$b$
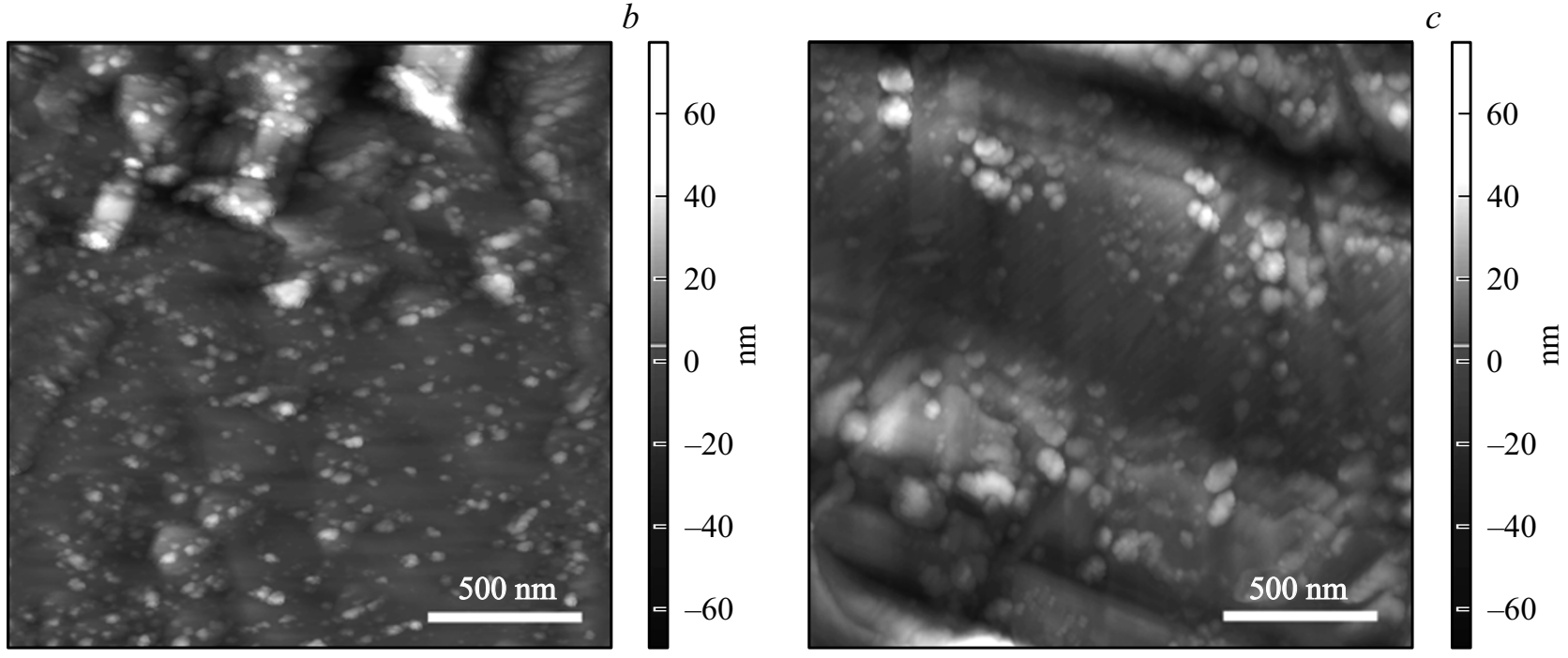

Рис. 2. СЭМ (a) и АСМ изображения $(b, c)$ поверхности образцов ППМ из губчатого Ті до анодирования. На вставке части $a-$ фотография образцов.

правило, для сканирования поверхности выбирались достаточно однородные участки. Вид АСМ изображений (рис. 4) также показал, что на микронеоднородной поверхности образцов после анодирования наблюдается появление наноструктурированного рельефа. Однако, наряду с участками, характеризуемыми наличием регулярно расположенных пор (рис. 4, $a$ ), выявлены и области, имеющие трубчатое строение (рис. $4, b$ ).

Принято считать [7,11-14], что причиной формирования при анодировании самоорганизованных оксидных пленок (как с пористой, так и с трубчатой мезоструктурой) является синергия процессов роста и растворения оксидной пленки, реализующаяся под действием электрического поля. Согласно [7,13,14], преобразование пор в нанотрубки при анодировании титана во фторсодержащих электролитах происходит из-за внедрения ионов фтора в тело оксидной пленки во время роста АОП. Однако на основе выявленного факта присутствия обла- стей АОП как с пористой, так и с трубчатой мезоструктурой, можно предположить, что на формирование самоорганизованных АОП влияет также и неоднородность рельефа анодируемой поверхности, в данном случае частиц порошка губчатого титана. Этот факт оказывает влияние на соотношение процессов роста и растворения (под действием F-ионов) формирующейся оксидной пленки на различных участках пористого образца, что и может явиться причиной появления областей как с нанотрубчатой, так и с нанопористой структурой оксида. Анализ АСМ изображений (рис. 4, $a, b$ ) дает для всех исследованных пленок близкие эффективные диаметры регулярных пор (рис. 4, $a$ ) и трубок (рис. 4,b), равные $\left\langle d_{p}\right\rangle=(50 \pm 15) \mathrm{nm}$. Данные значения укладываются в интервал значений $\left\langle d_{p}\right\rangle$, полученных при компьютерной обработке СЭМ изображений (рис. 3,e,f). Из АСМ изображений, полученных при сканировании областей с неоднородным рельефом, была выполнена оценка 

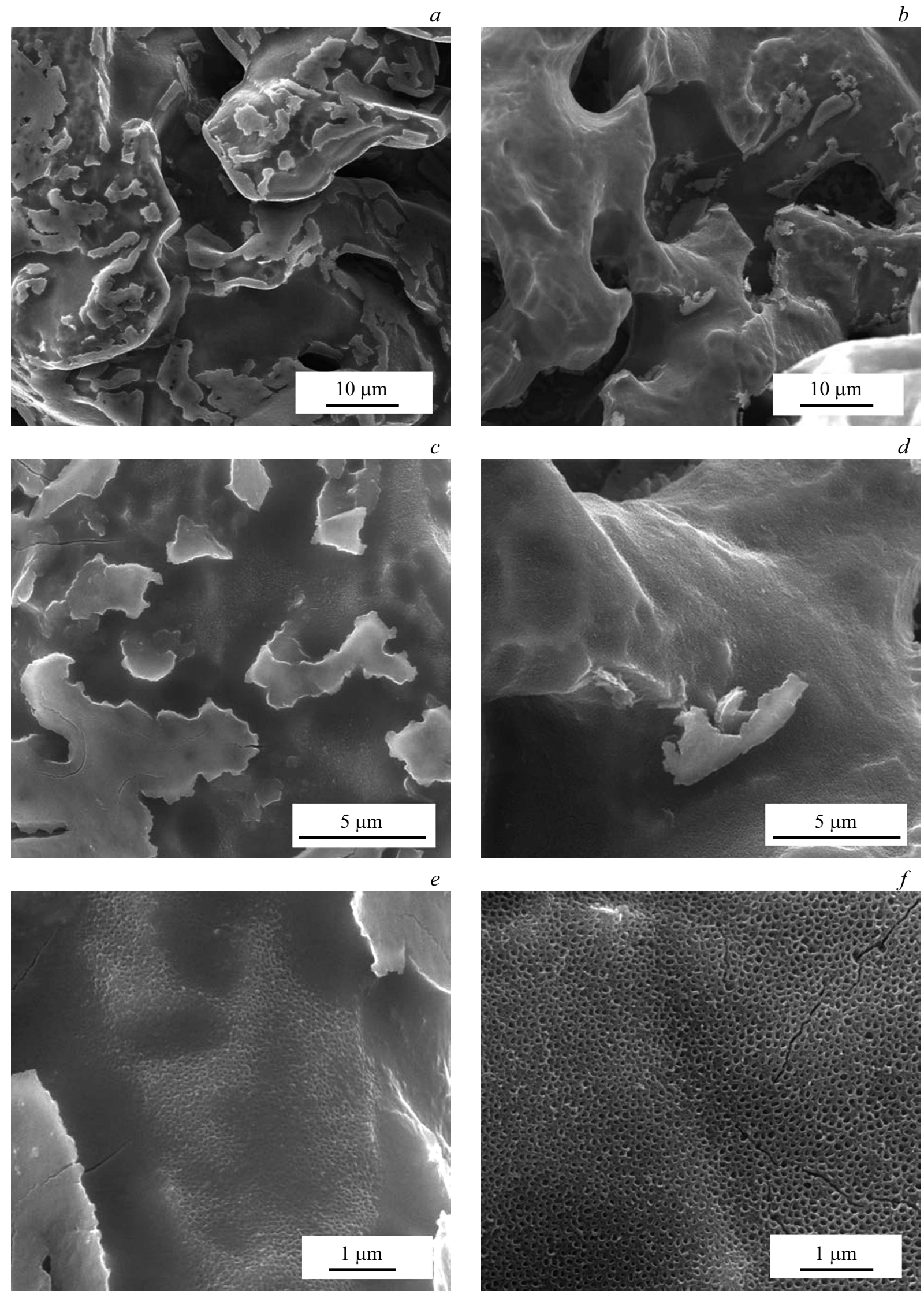

Pис. 3. СЭМ изображения поверхности образцов ППМ из губчатого Ті после анодирования в $10 \% \mathrm{H}_{2} \mathrm{SO}_{4}+0.15 \% \mathrm{HF}$ при

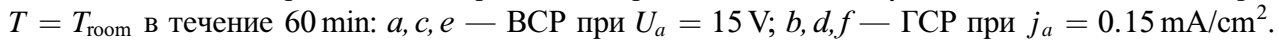



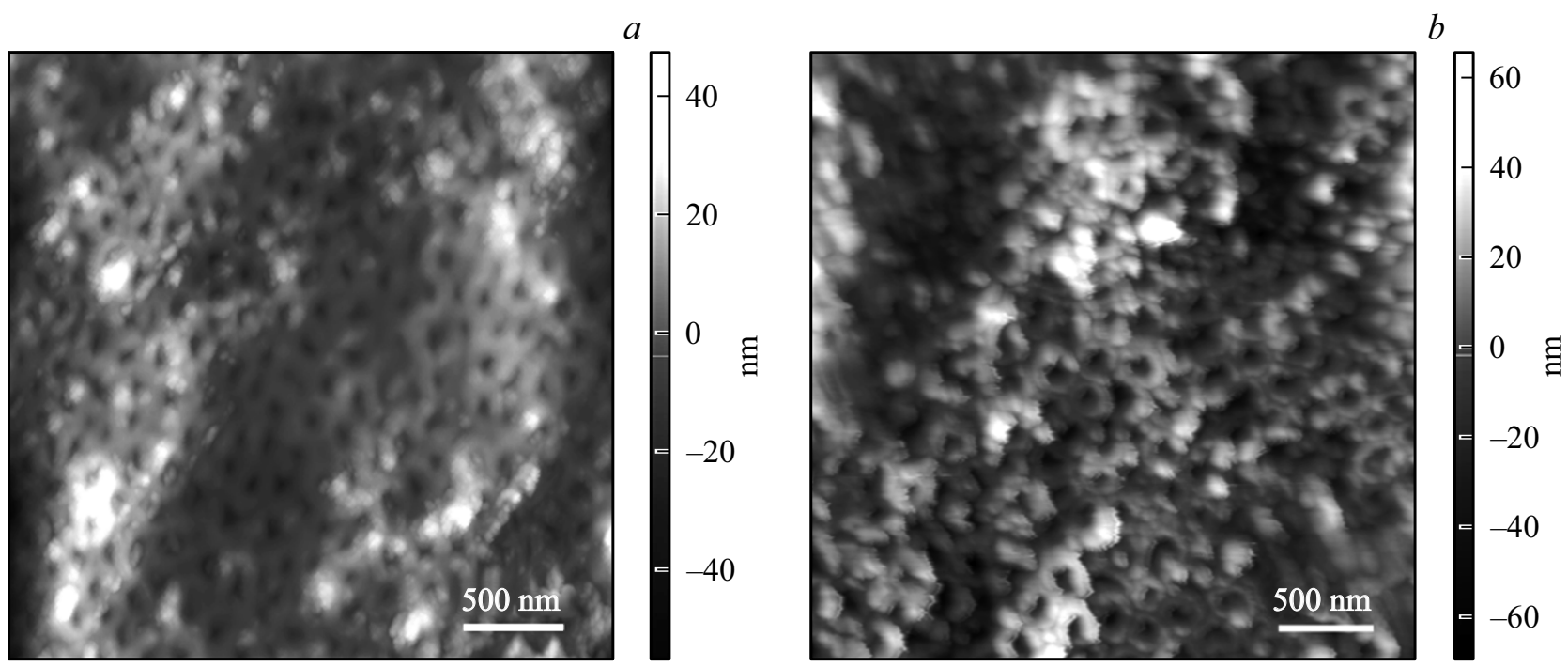

Рис. 4. АСМ изображения различных участков $(a, b)$ поверхности образцов ППМ из губчатого Ті после гальваностатического анодирования в $10 \% \mathrm{H}_{2} \mathrm{SO}_{4}+0.15 \% \mathrm{HF}$ при $j_{a}=0.15 \mathrm{~mA} / \mathrm{cm}^{2}, T=T_{\text {room }}, t_{a}=60 \mathrm{~min}$.

толщины формируемого пористого/трубчатого оксидного слоя. Ее значение находится в диапазоне от 250 до $350 \mathrm{~nm}$, что соответствует приводимым в литературе данным о толщине АОП, полученных анодированием титановой фольги в аналогичных условиях [7,11-14].

Рентгенографирование показало, что на дифрактограммах анодированных образцов ППМ губчатого титана присутствуют лишь брэгговские пики титановой подложки, дополнительных дифракционных максимумов не выявляется [20]. Данный факт позволяет предположить, что сформированные оксидные пленки являются рентгеноаморфными.

Таким образом, анодирование исследованных образцов спеченных порошков губчатого титана в $10 \% \mathrm{H}_{2} \mathrm{SO}_{4}+0.15 \% \mathrm{HF}$ в течение $60 \mathrm{~min}$ и комнатной температуре электролита как в гальваностатическом режиме при $j_{a}=0.15 \mathrm{~mA} / \mathrm{cm}^{2}$, так и вольтстатическом режиме при $U_{a}=15 \mathrm{~V}$ приводит к формированию на их поверхности рентгеноаморфных самоорганизованных оксидных пленок со средним эффективным диаметром пор/трубок в диапазоне от 30 до $70 \mathrm{~nm}$, толщиной от 250 до $350 \mathrm{~nm}$.

Известно [1], что смачиваемость и топография поверхности имплантата имеют первостепенное значение для оптимизации адгезии, распространения и разрастания клеток биологической ткани, а следовательно, напрямую характеризуют уровень биосовместимости. Гидрофильная поверхность имплантата является более предпочтительной по сравнению с гидрофобной, поскольку именно смачиваемость влияет на способность поверхности взаимодействовать с биологическими жидкостями, клеточными элементами, что имеет особенное значение на ранних этапах остеоинтеграции. Соответственно чем меньше краевой угол смачивания, тем выше абсорбционные свойства имплантируемого материала. Изучение смачивания образцов ППМ из губчатого порошка титана

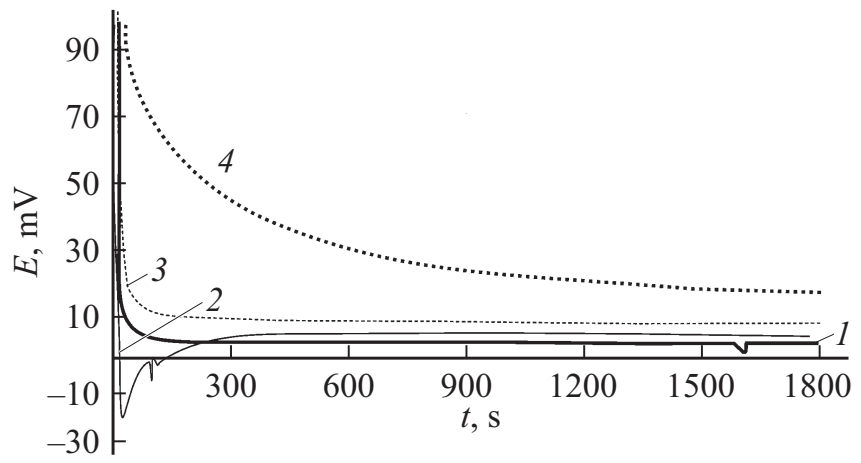

Рис. 5. Зависимости потенциала разомкнутой цепи от времени выдержки образцов в растворе Рингер-Локка: 1,2 - до анодирования; 3, 4 - после анодирования $10 \% \mathrm{H}_{2} \mathrm{SO}_{4}+0.15 \% \mathrm{HF}$ при $j_{a}=0.15 \mathrm{~mA} / \mathrm{cm}^{2}, T=T_{\text {room }}, t_{a}=60 \mathrm{~min}$. Время выдержки $6 \mathrm{~h}$, показан начальный участок.

показали [20], что поверхность образцов до анодирования является гидрофобной, поскольку среднестатистическое значение краевого угла смачивания, измеренного для различных частиц губчатого титана, составляет $\theta=(102 \pm 15)^{\circ}$. В то же время после анодирования образцов при оптимальных параметрах процесса поверхность становится гидрофильной, поскольку капля жидкости моментально впитывается.

Для оценки влияния анодирования в $10 \% \mathrm{H}_{2} \mathrm{SO}_{4}+$ $+0.15 \% \mathrm{HF}$ на коррозионную стойкость образцов был использован метод контроля потенциала разомкнутой цепи (ПРЦ). Изменение ПРЦ с течением времени дает информацию о процессах на поверхности образца (образование пассивного слоя и/или его разрушение) или их отсутствии, т.е. невосприимчивости к воздействию среды. На рис. 5 представлены зависимости ПРЦ от времени выдержки в растворе Рингер-Локка для об- 
разцов губчатого титана до и после анодирования. Ход зависимостей для анодированных образцов позволяет говорить, что присутствие на поверхности ППМ из губчатого титана анодно-оксидной пленки обеспечивает необходимую коррозионную стойкость образцов $[21,26]$.

Таким образом, в результате модификации поверхности пористых порошковых материалов из губчатого титана методом электрохимического анодирования во фторсодержащем электролите формируется биоактивная нанопористая/нанотрубчатая оксидная пленка, обеспечивающая гидрофильность и коррозионную стойкость поверхности. Полученные результаты могут служить основой дальнейших исследований для разработки имплантатов на основе анодно-модифицированных спеченных порошков губчатого титана.

\section{Заключение}

1. Впервые показано, что при оптимальных условиях анодирования во фторсодержащем водном электролите $10 \% \mathrm{H}_{2} \mathrm{SO}_{4}+0.15 \% \mathrm{HF}$ на поверхности образцов пористых порошковых материалов из губчатого титана происходит формирование рентгеноаморфных самоорганизованных наноструктурированных пленок $\mathrm{TiO}_{2}$ с размерами пор/трубок в диапазоне от 30 до $70 \mathrm{~nm}$, толщиной от 250 до $350 \mathrm{~nm}$.

2. Показано, что метод полуконтактной АСМ может быть эффективно использован для изучения строения поверхности порошковых материалов из губчатого титана.

3. Полученные результаты подтверждают перспективность применения такого способа модификации поверхности при изготовлении биоактивных имплантатов из спеченных порошков губчатого титана.

Работа выполнена при поддержке РФФИ грант № 15-58-04086 Бел_мол_а и БРФФИ по договору T15PM-062.

\section{Список литературы}

[1] Савич В.В., Сарока Д.И., Киселев М.Г., Макаренко М.В. Модификация поверхности титановых имплантатов и ее влияние на их биомеханические параметры в биологических средах. Минск: Беларуская навука, 2012. 244 с.

[2] Alvarez K., Nakajima H. // Materials. 2009. Vol. 2. P. 790 832. DOI: $10.3390 / \mathrm{ma} 2030790$

[3] Wally Z.J., van Grunsven W., Claeyssens F., Goodall R., Reilly G.C. // Metals. 2015. Vol. 5. P. 1902-1920. DOI: $10.3390 /$ met5041902

[4] Шелухина А.И. // Полимерные материалы и технологии. 2015. Т. 1. № 2. С. 62-67.

[5] Савич В.В., Бобровская А.И., Тарайкович А.М., Беденко C.A. // Нанотехнологии функциональных материалов (НФМ'12): труды международной научно-технической конференции. СПб: изд-во Политехн. ун-та., 2012. С. $523-$ 529.

[6] Nagesh Ch. R.V.S., Ramachandran C.S., Subramanyam R.B. // T. Indian I. Metals. 2008. Vol. 61. N 5. P. 341-348.
[7] Lee K., Mazare A., Schmuki P. // Chem. Rev. 2014. Vol. 114. P. 9385-9454.

[8] Yang B., Uchida M., Kim H.-M., Zhang X., Kokubo T. // Biomaterials. 2004. Vol. 25. P. 1003-1010.

[9] Hamouda I.M., El-wassefy N.A., Marzook H.A., Habib A.N., El-deen A., El-awady G.Y. // European J. Biotechnol. Biosci. 2014. Vol. 1. N 3. P. 17-26.

[10] Fan X., Feng B., Weng J., Wang J., Lu X. // Mater. Lett. 2011. Vol. 65. P. 2899-2901.

[11] Macak J.M., Tsuchiya H., Ghicov A., Yasuda K., Hahn R., Bauer S., Schmuki P. // Curr. Opin. Solid St. M. 2007. Vol. 11. P. 3-18.

[12] Regonini D., Bowen C. R., Jaroenworaluck A., Stevens R. // Mat. Sci. Eng. R. 2013. Vol. 74. P. 377-406.

[13] Kulkarni M., Mazare A., Gongadze E., Perutkova Š., KraljIglic V., Milošev I., Schmuki P., Iglic A., Mozetic M. // Nanotechnology. 2015. Vol. 26. P. 1-18.

[14] Zhou X., Nguyen N.T., Özkan S., Schmuki P. // Electrochem. Commun. 2014. Vol. 46. P. 157-162.

[15] Beltran-Partida E., Valdez-Salas B., Moreno-Ulloa A., Escamilla A., Curiel M.A. et al. // J. Nanobiotechnol. 2017. Vol. 15. N 10. P. 1-21. DOI 10.1186/s12951-017-0247-8

[16] Wang Q., Cheng M., He G., Zhang X. // J. Nanomater. 2015. 408634. 10 p. http://dx.doi.org/10.1155/2015/408634

[17] Lee J.-H., Kim H.-E., Koh Y.-H. // Mater. Lett. 2009. Vol. 63. P. 1995-1998.

[18] Макарова Э.Б., Захаров Ю.М., Рубштейн А.П., Исайкин А.И. // Гений ортопедии. 2011. № 4. С. 111-116.

[19] Шелухина А.И., Степанова К.В., Кокатев А.Н., Толстик B.E. // Порошковая металлургия. 2015. № 38. C. $180-184$.

[20] Кокатев А.Н., Степанова К.В., Яковлева Н.М., Шелухина А.И., Толстик В.Е. // Труды Кольского научного центра РАН. Химия и материаловедение. 2015. № 5 (31). С. 375 379.

[21] Кокатев А.Н., Степанова К.В., Яковлева Н.М., Шульга А.М., Шелухина А.И., Толстик В.Е. // Сб. докл. 10-го междунар. симп. „Порошковая металлургия: инженерия поверхности, новые порошковые композиционные материалы. Сварка“. Минск, 2017. Минск: Беларуская навука, 2017. Ч. 2. С. $307-316$.

[22] Gong D., Grimes C.A., Varghese O.K., Hu W., Singh R.S., Chen Z., Dickey E.C. // J. Mater. Res. 2001. Vol. 16. N 12. P. 3331-3334.

[23] Степанова К.В., Яковлева Н.М., Кокатев А.Н., Петтерссон X. // Ученые записки ПетрГУ. 2015. Т. 147. № 2. C. $81-86$.

[24] Яковлева Н.М., Яковлев А.Н., Гафиятуллин М.М., Денисов А.И. // Диагностика материалов. 2009. Т. 75. № 2. C. 21-26.

[25] Nielsh K., Choi J., Schwirn K., Wehrspohn R., Gösele U. // Nano Lett. 2002. Vol. 2. N 7. P. 676-680.

[26] Alves A.C., Wenger F., Ponthiaux P., Celis J.-P., Pinto A.M., Rocha L.A., Fernandes J.C.S. // Electrochim. Acta. 2017. Vol. 234. P. 16-27. 